\title{
Perbedaan Risiko Pneumonia Berdasarkan Pola Asuh dan Paparan Asap Rokok
}

\section{Differences in Risk of Pneumonia Based on Parenting and Exposure to Cigarette Smoke}

\author{
Fatati Larasati ${ }^{1)}$, Arief Hargono ${ }^{2)}$ \\ ${ }^{1,2}$ Departemen Epidemiologi, Fakultas Kesehatan Masyarakat, Universitas Airlangga, Surabaya \\ Email: fatati.11@gmail.com
}

\begin{abstract}
Background: One of the infectious diseases which is the main cause of the high infant mortality rate in the world is pneumonia. Many factors can increase the incidence of pneumonia in children under 4 years old, including mothers' knowledge and attitudes about parenting and the existence of family members who smoke, the number of family members who smoke, and smoking areas of family members who smoke (exposure to cigarette smoke). Purpose: The purpose of this study was to analyze differences in pneumonia risk based on parenting and exposure to cigarette smoke in children under 4 years. Method: This study used a case control study design with 50 respondents using a ratio of 1: 4 (10 cases and 40 controls). Case criteria are children under 4 years of age who have been diagnosed with pneumonia by a doctor or paramedic in April-May 2018 and control criteria are children under 4 years old who have not been diagnosed with pneumonia or other diseases by a doctor or paramedics. The research was carried out by Bulak Banteng Health Center in April-May 2018 with interviews using a questionnaire. Data analysis was performed by univariate and bivariate analysis using the Chi Square test. Results: The results showed that smoking places had the greatest difference in the risk of pneumonia in children under 4 years (44.62\%), while the other factors ranked from the largest RD were knowledge of health practices at home (32\%), the presence of family members who smoked ( 27.3\%), the number of family members who smoke (20\% 5), and the attitude of health practice at home (9.6\%). Conclusion: The biggest risk difference (RD) for the incidence of pneumonia in children 0-4 years old is the smoking place variable of family members who smoke, then followed by the variable knowledge of health practices at home, the presence of family members who smoke, the number of family members who smoke, and who have risks the smallest is the attitude of the mother in the practice of health at home.
\end{abstract}

Keywords: Pneumonia, Pneumonia Risk, Children, Mother Caring Pattern, Exposure to Cigarette Smoke

\begin{abstract}
ABSTRAK
Latar Belakang: Salah satu penyakit infeksi yang menjadi penyebab utama tingginya Angka Kebatian Bayi di dunia adalah pneumonia. Banyak faktor yang dapat meningkatkan angka kejadian pneumonia pada anak dibawah 4 tahun, termasuk pengetahuan dan sikap ibu tentang pola asuh dan keberadaan anggota keluarga yang merokok, jumlah anggota keluarga yang merokok, serta tempat merokok anggota keluarga yang merokok (paparan asap rokok). Tujuan: Tujuan penelitian ini untuk menganalisis perbedaan risiko pneumonia berdasarkan pola asuh ibu dan paparan asap rokok pada anak dibawah 4 tahun. Metode: Penelitian ini menggunakan rancang bangun penelitian case control dengan 50 responden menggunakan perbandingan 1:4 (10 kasus dan 40 kontrol). Kriteria kasus adalah anak berumur dibawah 4 tahun yang didiagnosis pneumonia oleh dokter atau paramedis pada Bulan April-Mei 2018 dan kriteria kontrol adalah anak berumur dibawah 4 tahun yang tidak didiagnosis pneumonia atau penyakit lainnya oleh dokter atau paramedis. Penelitian ini dilakukan Puskesmas Bulak Banteng pada bulan April-Mei 2018 dengan wawancara menggunakan kuesioner. Analisis data dilakukan dengan analisis univariat dan bivariat menggunakan uji Chi Square. Hasil: Hasil penelitian menunjukkan
\end{abstract}


bahwa tempat merokok memiliki perbedaan besar risiko pneumonia pada anak dibawah 4 tahun terbesar (44,62\%), sedangkan faktor lainnya diurutkan dari RD terbesar yaitu pengetahuan praktik kesehatan di rumah (32\%), keberadaan anggota keluarga yang merokok (27,3\%), jumlah anggota keluarga yang merokok (20\%5), dan sikap praktik kesehatan di rumah (9,6\%). Kesimpulan: Perbedaan risiko (RD) terbesar untuk kejadian pneumonia anak 0-4 tahun adalah variabel tempat merokok anggota keluarga yang merokok, kemudian diikuti variabel pengetahuan praktik kesehatan di rumah, keberadaan anggota keluarga yang merokok, jumlah anggota keluarga yang merokok, dan yang memiliki risiko terkecil adalah sikap ibu dalam praktik kesehatan di rumah.

Kata Kunci : Pneumonia, Risiko Pneumonia, Anak, Pola Asuh Ibu, Paparan Asap Rokok

\section{PENDAHULUAN}

Pneumonia merupakan salah satu penyakit infeksi yang ditandai dengan peradangan pada satu atau kedua paruparu yang dapat disebabkan oleh virus, jamur, bakteri sehingga menyebabkan berkurangnya kemampuan kantungkantung udara untuk menyerap oksigen (Misnadiarly, 2008). Pneumonia disebut juga sebagai "The Forgotten Killer of Children" atau pembunuh balita yang terlupakan sebagai akibat kurang perhatiannya masyarakat dalam menangani kasus pneumonia dimana 2 dari 9 juta kematian balita di dunia telah disebabkan oleh pneumonia (Kementerian Kesehatan RI, 2011).

Data hasil Survei Penduduk Antar Sensus (SUPAS) 2015 menunjukkan proporsi angka kematian bayi sebesar 22,23 per mil kelahiran hidup, proporsi kematian balita sebesar 26,29 per mil kelahiran hidup, meskipun hasil ini telah memenuhi target MDG's (32 per mil kelahiran hidup), proporsi AKB dan AKABA ini dinilai masih cukup tinggi (Kemenkes RI, 2017). Estimasi data kematian balita tahun 2012-2016 menunjukkan 16\% kematian balita dikarenakan Acute Respiratory Infection. Penyakit infeksi utama pada balita yang menyebabkan kematian masih dikarenakan penyakit pneumonia (UNICEF, 2018). Data global UNICEF (2018) menunjukkan bahwa pada tahun 2016, pneumonia masih menjadi penyebab kematian balita di Indonesia dengan menempati urutan kedua $(16 \%)$ setelah preterm (19\%).

Data riskesdas tahun 2013 menunjukkan bahwa period prevalence pneumonia di Provinsi Jawa Timur mendekati rata-rata period prevalence pneumonia di Indonesia (1,8\%). Data kesehatan Kota Surabaya menunjukkan angka kasus pneumonia yang tinggi meskipun telah mengalami penurunan kasus dari tahun 2015 sebanyak 4018 kasus menjadi 3925 kasus pada tahun 2016. Tahun 2015, wilayah kerja Puskesmas Bulak Banteng menunjukkan angka penemuan kasus pneumonia balita sebesar 480 balita dari 3262 balita di Kota Surabaya $(14,7 \%)$ (Badan Penelitian dan Pengembangan Kesehatan, 2013)..

Angka kematian bayi dan balita dapat diturunkan dengan cara melakukan penanganan penyakit secara komprehensif, serius, dan berkualitas seperti mendata kembali bayi-bayi yang berupaya untuk drop out dari sasaran program imunisasi, dan penanganan dini terhadap gangguan gizi pada bayi, balita dan ibu hamil, serta menerapkan pola asuh yang baik dan tepat (Djaja, Wiryawan and Maisya, 2007).

Teori UNICEF (United Nations International Children's Emergency Fund) menyatakan bahwa timbulnya suatu penyakit infeksi disebabkan pola asuh ibu yang salah terhadap anak, sanitasi yang tidak memadai, kurangnya air bersih serta pelayanan fasilitas kesehatan dasar yang buruk (Handayani, 2017). Pola asuh ibu dikatakan tepat jika memenuhi 6 kunci utama diantaranya melakukan perawatan dan perlindungan anak, menyusui dan memberikan MP-ASI, pengasuhan psikososial, penyiapan makanan yang sesuai, menjaga kebersihan dan sanitasi lingkungan anak serta pola ibu dalam membawa anaknya ke pelayanan kesehatan dan upaya ibu dalam melakukan praktik kesehatan di rumah (Setiyarti, 2011). Dalam upaya menerapkan praktik kesehatan di rumah 
ibu harus bisa menjaga kebersihan anak, mencukupi kebutuhan cairan anak, dan melakukan perawatan anak yang sakit (Kemenkes RI, 2017).

Perilaku praktik kesehatan di rumah akan dapat dengan mudah diterapkan jika ibu memiliki pengetahuan dan sikap yang tinggi tentang tata cara melakukan praktik kesehatan di rumah (Klein, 2015). Perilaku seseorang dapat dipengaruhi oleh 3 faktor yaitu pengetahuan, sikap, tindakan. Ibu memegang peranan penting dalam kesehatan anak (Anggraini, 2015).

H.L. Blum mengungkapkan bahwa kesehatan juga dipengaruhi oleh faktor lingkungan dimana faktor lingkungan bersama dengan faktor perilaku memberikan kontribusi $70 \%$ terhadap status kesehatan seseorang (Ryadi, 2016). Paparan asap rokok juga merupakan penyebab anak terkena pneumonia. Penelitia sebelumnya mengungkapkan bahwa anak yang mempunyai anggota keluarga seorang perokok memiliki risiko 8,5 kali terkena pneumonia dibandingkan dengan tidak memiliki anggota keluarga perokok (Nuretza, Suhartono and Winarni, 2017).

Kandungan zat dalam asap rokok dapat merangsang pembentukan lendir, debu, dan bakteri yang menyebabkan udara bertahan di paru-paru dan memecahkan kantong udara pada paruparu. Balita lebih mudah terkena pneumonia daripada orang dewasa karena balita tidak dapat mengeluarkan lendir yang dibentuk oleh zat- zat dalam asap rokok (Widiawati dalam Wardani, et al., 2015).

Hasil uraian diatas telah menunjukkan bahwa penelitian ini akan mengkaji lebih lanjut mengenai perbedaan risiko pneumonia pada anak umur 0-4 tahun berdasarkan pola asuh ibu dan paparan asap rokok.

\section{METODE}

Jenis penelitian ini adalah observasional analitik karena tidak ada perlakuan yang diberikan peneliti pada subyek penelitian. Penelitian ini menggunakan rancang bangun penelitian case control karena peneliti akan menganalisis hubungan antara variabel dependen (kejadian pneumonia anak 0-4 tahun) dengan variabel independen (pola asuh ibu dan paparan asap rokok). Subyek yang terlibat dalam penelitian akan terbagi ke dalam kelompok kasus dan kelompok kontrol.

Penelitian dilakukan di wilayah kerja Puskesmas Bulak Banteng dan pengambilan data dilakukan dari bulan April-Mei 2018. Populasi penelitian ini ada 2 yaitu populasi kasus dan populasi kontrol. Populasi kasus semua anak berusia 0-4 tahun yang melakukan kunjungan ke Puskesmas Bulak Banteng pada bulan April-Mei 2018 serta telah didiagnosis pneumonia oleh dokter atau paramedis. Populasi kontrol terdiri dari semua anak berusia 0-4 tahun yang melakukan kunjungan ke Puskesmas Bulak Banteng pada Bulan April-Mei 2018 serta tidak didiagnosis pneumonia ataupun penyakit lainnya oleh dokter atau paramedis.

Pengambilan sampel dilakukan menggunakan metode non-probability sampling method melalui total sampling dengan jumlah sampel kasus sebanyak 10 orang dan pada sampel kontrol melalui perbandingan 1:4 didapatkan hasil 40 orang, sehingga jumlah sampel kontrol dan sampel kasus berjumlah 50 orang. Pengambilan sampel kontrol dilakukan dengan cara accidental sampling.

Variabel dependen adalah kejadian pneumonia anak 0-4 tahun. Variabel independen antara lain pola asuh ibu (pengetahuan praktik kesehatan di rumah dan sikap praktik kesehatan di rumah) dan paparan asap rokok (keberadaan anggota merokok, jumlah perokok, dan tempat merokok).

Peneliti mengumpulkan dua jenis data, yaitu data primer dan sekunder. Data primer dikumpulkan secara langsung dengan wawancara menggunakan kuesioner. Data sekunder dilakukan dengan cara mengumpulkan data dari instansi, seperti data laporan kesehatan Indonesia dari kementerian kesehatan, data profil kesehatan Provinsi Jawa Timur dan Kota Surabaya yang diperoleh secara online serta laporan pemegang program penyakit menular (pneumonia) yang diperoleh secara offline.

Analisis data yang digunakan adalah analisis univariat yang ditujukan untuk mendeskripsikan variabel-variabel di dalam penelitian dan analisis bivariate dengan uji chi square untuk mengetahui hubungan antar variabel. Data dianalisis dengan mencari nilai OR (Odds Ratio) dan nilai $R D$ (Risk Difference). 


\section{HASIL DAN PEMBAHASAN}

Karakteristik anak yang didapatkan antara lain umur, jenis kelamin, serta urutan kelahiran dapat dilihat pada Tabel 1. Tabel 1 menunjukkan bahwa dari 50 responden dalam penelitian yaitu pada karakteristik umur sebagian besar kelompok kasus berada pada kelompok umur 13-24 bulan sedangkan kelompok kontrol berada pada kelompok umur 0-12 bulan. Baik sampel kasus maupun sampel kontrol mayoritas berjenis kelamin laki- laki serta mayoritas sampel merupakan anak sulung.

Tabel 1. Karakteristik Anak

\begin{tabular}{lll}
\hline \multicolumn{1}{c}{ Karakteristik } & \multicolumn{1}{c}{$\begin{array}{c}\text { Kasus } \\
\text { (\%) }\end{array}$} & $\begin{array}{c}\text { Kontrol } \\
\text { (\%) }\end{array}$ \\
\hline Umur (bulan) & & \\
\hline $0-12$ & 40 & 30 \\
$13-24$ & 60 & 20 \\
$25-36$ & 0 & 27,5 \\
$37-48$ & 0 & 22,5 \\
\hline Total & 100 & 100 \\
\hline Jenis Kelamin & & \\
\hline Perempuan & 40 & 37,5 \\
Laki- Laki & 60 & 62,5 \\
\hline Total & 100 & 100 \\
\hline Urutan Kelahiran & & \\
\hline 1 & 60 & 52,5 \\
2 & 40 & 27,5 \\
3 & 0 & 20 \\
\hline Total & 100 & 100 \\
\hline
\end{tabular}

Tabel 2. Karakteristik Ibu

\begin{tabular}{lll}
\hline \multicolumn{1}{c}{ Karakteristik } & \multicolumn{1}{c}{$\begin{array}{c}\text { Kasus } \\
\text { (\%) }\end{array}$} & $\begin{array}{c}\text { Kontrol } \\
\text { (\%) }\end{array}$ \\
\hline Usia & 0 & 7,5 \\
\hline$\leq 20$ & 80 & 32,5 \\
$21-25$ & 20 & 30 \\
$26-30$ & 0 & 20 \\
$31-35$ & 0 & 10 \\
$36-40$ & 100 & 100 \\
\hline Total & & \\
\hline Pendidikan & 0 & 2,5 \\
\hline Tidak Lulus SD & 60 & 15 \\
Lulus SD/Sederajat & 40 & 40 \\
Lulus SMP/Sederajat & 0 & 32,5 \\
Lulus SMA/ Sederajat & 0 & 10 \\
Lulus Perguruan Tinggi & 100 & 100 \\
\hline Total & & \\
\hline Status Pekerjaan & 80 & 82,5 \\
\hline Tidak Bekerja & 20 & 17,5 \\
Bekerja & 100 & 100 \\
\hline Total & & \\
\hline Penghasilan Keluarga & & 92,5 \\
\hline$\leq$ UMR Kota Surabaya & 100 & 7,5 \\
\hline$>$ UMR Kota Surabaya & 0 & 100 \\
\hline Total & 100 & \\
\hline
\end{tabular}

Sedangkan pada Tabel 2. karakteristik ibu, mayoritas ibu berada pada kelompok umur 21-25 tahun baik pada sampel kasus maupun sampel kontrol. Tingkat pendidikan pada sampel kasus maupun sampel kontrol mayoritas berada pada tingkat pendidikan rendah ( $\leq$ SMA) dengan sampel kasus mayoritas lulusan SD, sedangkan mayoritas sampel kontrol mempunyai tingkat pendidikan lulusan SMP. Baik sampel kasus maupun sampel kontrol mayoritas tidak bekerja atau merupakan ibu rumah tangga serta penghasilan keluarga baik pada sampel kasus maupun sampel kontrol mayoritas masih dibawah UMR Kota Surabaya (Rp 3.583.312).

Pengetahuan dan sikap ibu tentang praktik kesehatan di rumah terdapat tiga tingkat yaitu baik, sedang, dan kurang. Tingkatan ini diketahui dari hasil komplisit 3 sub variabel praktik kesehatan di rumah yaitu kebersihan anak, kebutuhan cairan anak, dan perawatan anak sakit.

Tabel 3. menunjukkan tingkatan pengetahuan pada masing-masing sub variabel diantaranya pada variabel pengetahuan, sub variabel pengetahuan praktik kesehatan di rumah yaitu kebersihan anak dan perawatan anak sakit, mayoritas sampel kasus memiliki tingkat pengetahuan sedang. Mayoritas sampel kasus pada sub variabel kebutuhan cairan anak memiliki tingkat pengetahuan kurang. Berbeda dengan mayoritas sampel kontrol memiliki tingkat pengetahuan baik dalam semua sub variabel praktik kesehatan di rumah.

Mayoritas sampel kasus pada sikap praktik kesehatan di rumah, maupun sampel kontrol tidak ada yang memiliki sikap praktik kesehatan di rumah dalam tingkatan kurang. Baik sampel kasus maupun sampel kontrol memiliki tingkatan sikap yang baik pada sub variabel kebersihan anak dan kebutuhan cairan anak. Mayoritas sampel kasus pada sub variabel perawatan anak sakit, memiliki tingkatan sikap sedang sedangkan sampel kontrol mayoritas memiliki tingkatan sikap baik.

Kebermaknaan hubungan antara pola asuh ibu (pengetahuan praktik dengan sikap praktik kesehatan di rumah) dan paparan asap rokok (keberadaan anggota keluarga yang merupakan perokok, jumlah anggota keluarga yang merupakan perokok, dan tempat merokok 
anggota keluarga yang merupakan perokok) dengan kejadian pneumonia dapat diketahui dari nilai $P$ Value, selain itu besar nilai risiko dari variabel independen dengan variabel dependen dapat diketahui dengan melihat nilai $O R$
(Odds Ratio). Perbandingan risiko antara variabel-variabel independen dengan variabel dependen dapat dilihat dari nilai $R D$ (Risk Difference). Ketiga nilai diatas $(P$ Value, $O R$, dan $R D$ ) disajikan dalam tabel 4.

Tabel 3. Tingkat Pengetahuan dan Sikap Sub Variabel Praktik Kesehatan Di Rumah

\begin{tabular}{|c|c|c|c|c|c|c|c|c|}
\hline \multirow{3}{*}{ Variabel } & \multicolumn{4}{|c|}{ Tingkat Pengetahuan } & \multicolumn{4}{|c|}{ Tingkat Sikap } \\
\hline & \multicolumn{2}{|c|}{ Kasus } & \multicolumn{2}{|c|}{ Kontrol } & \multicolumn{2}{|c|}{ Kasus } & \multicolumn{2}{|c|}{ Kontrol } \\
\hline & $\mathrm{n}$ & $\%$ & $\mathrm{n}$ & $\%$ & $\mathbf{n}$ & $\%$ & $\mathrm{n}$ & $\%$ \\
\hline \multicolumn{9}{|c|}{ Kebersihan Anak } \\
\hline Baik & 2 & 20 & 22 & 55 & 10 & 100 & 33 & 82,5 \\
\hline Sedang & 7 & 70 & 10 & 25 & 0 & 0 & 7 & 7,5 \\
\hline Kurang & 1 & 10 & 8 & 20 & 0 & 0 & 0 & 0 \\
\hline Total & 10 & 100 & 40 & 100 & 10 & 100 & 40 & 100 \\
\hline \multicolumn{9}{|c|}{ Kebutuhan Cairan Anak } \\
\hline Baik & 3 & 30 & 28 & 70 & 7 & 70 & 29 & 72,5 \\
\hline Sedang & 2 & 20 & 9 & 22,5 & 3 & 30 & 11 & 27,5 \\
\hline Kurang & 5 & 50 & 3 & 7,5 & 0 & 0 & 0 & 0 \\
\hline Total & 10 & 100 & 40 & 100 & 10 & 100 & 40 & 100 \\
\hline \multicolumn{9}{|c|}{ Perawatan Anak Sakit } \\
\hline Baik & 2 & 20 & 30 & 75 & 3 & 30 & 24 & 60 \\
\hline Sedang & 5 & 50 & 10 & 25 & 7 & 70 & 16 & 40 \\
\hline Kurang & 3 & 30 & 0 & 0 & 0 & 0 & 0 & 0 \\
\hline Total & 10 & 100 & 40 & 100 & 10 & 100 & 40 & 100 \\
\hline
\end{tabular}

Tabel 4. menunjukkan sebagian besar kasus mempunyai ibu yang memiliki pengetahuan praktik kesehatan di rumah dengan tingkat kurang dan sedang, Sebagian sampel kontrol mempunyai ibu yang memiliki pengetahuan praktik kesehatan di rumah dengan tingkat baik. Sikap praktik kesehatan di rumah, baik sampel kasus maupun sampel kontrol memiliki sikap praktik kesehatan di rumah dengan tingkat yang baik.

Analisis data menunjukkan bahwa terdapat perbedaan hasil antara pengetahuan dan sikap ibu dalam melakukan praktik kesehatan di rumah. Variabel pengetahuan ibu memiliki hubungan yang signifikan dengan kejadian pneumonia anak 0-4 tahun ( $P$ Value $<0,05)$. Keberadaan anggota keluarga yang merokok dan tempat merokok anggota keluarga yang merokok pada variabel paparan asap rokok juga memiliki hubungan yang signifikan dengan kejadian pneumonia anak 0-4 tahun ( $P$ Value $<0,05)$.

Tabel 4 menunjukkan mayoritas sampel kasus memiliki anggota keluarga yang merokok. Mayoritas sampel kasus dan kontrol memiliki anggota keluarga yang merokok sebanyak $\leq 2$ orang.

Hasil penelitian menunjukkan besarnya perbedaan risiko terbesar yaitu pada variabel tempat merokok. Hal ini menunjukkan perbandingan kejadian pneumonia anak yang mempunyai anggota keluarga dengan kebiasaan merokok di luar dan di dalam rumah dengan anak 0-4 tahun yang mempunyai anggota keluarga dengan kebiasaan merokok di luar rumah saja yaitu sebesar 44,6\%. Perbedaan besar risiko $(R D)$ terkecil ada pada sikap praktik kesehatan di rumah yakni sebesar 9,6\%.

Faktor risiko terbesar adalah pada variabel pengetahuan praktik kesehatan di rumah yakni dengan risiko terkena pneumonia 13,5 kali lebih besar dibandingkan dengan anak yang memiliki pengetahuan praktik kesehatan di rumah pada level tingkat baik. Faktor risiko terkecil adalah pada variabel sikap praktik kesehatan di rumah yang menunjukkan anak yang memiliki ibu dengan tingkat kurang dan sedang pada sikap praktik kesehatan di rumah akan memiliki risiko terkena pneumonia sebesar 1,758 kali daripada anak yang memiliki ibu dengan tingkat baik pada sikap praketk kesehatan di rumah. Hasil analisis faktor-faktor risiko tersebut tidak bermakna.

\section{Praktik Kesehatan Di Rumah}

Pengetahuan, sikap, dan tindakan merupakan faktor dalam pembentukan perilaku seseorang. 
Tingkat pengetahuan ibu berbanding lurus dengan perilaku ibu. Kondisi ini disebabkan karena pengetahuan membuat kita bisa memilih mana perilaku yang benar dan harus dilakukan atau mana perilaku yang buruk dan tidak harus dilakukan.

Hasil penelitian ini didukung oleh Handayani (2016) tentang faktor risiko pneumonia balita yang berada di Kecamatan Kalikajar Kabupaten Wonosobo. Handayani (2016) menyebutkan, pengetahuan ibu tentang pneumonia merupakan salah satu faktor risiko karena dalam penelitian tersebut menyatakan bahwa balita yang mempunyai ibu berpengetahuan kurang mempunyai risiko menderita pneumonia sebesar 4,15 kali daripada balita yang mempunyai ibu berpengetahuan baik (Handayani, 2016). Penelitian yang dilakukan oleh Tazinya, et al. (2018) pada 512 balita di Bamenda Regional Hospital, Cameroon juga menunjukkan hasil serupa, dimana balita dengan ibu berpengetahuan rendah terkait pola asuh ibu memiliki risiko terkena infeksi pernapasan akut sebesar 2,8 kali lebih besar dibandingkan balita yang mempunyai ibu berpengetahuan pola asuh ibu yang baik (Tazinya et al., 2018).

Tabel 4. Perbedaan Besar Risiko Pneumonia pada Anak 0-4 Tahun berdasarkan Pola Asuh Ibu dan Paparan Asap Rokok di Puskesmas Bulak Banteng

\begin{tabular}{|c|c|c|c|c|c|c|c|}
\hline \multirow{2}{*}{ Variabel Independen } & \multicolumn{2}{|c|}{ Kasus } & \multicolumn{2}{|c|}{ Kontrol } & \multirow{2}{*}{$\begin{array}{c}\text { Odds Ratio } \\
\text { (OR) } \\
(95 \% \mathrm{Cl}) \\
\end{array}$} & \multirow{2}{*}{$\begin{array}{c}P \\
\text { value }\end{array}$} & \multirow{2}{*}{$\begin{array}{c}\text { Risk } \\
\text { Difference } \\
\text { (RD) }\end{array}$} \\
\hline & $\mathrm{n}$ & $(\%)$ & $\mathrm{n}$ & (\%) & & & \\
\hline \multicolumn{8}{|l|}{ Pola Asuh Ibu } \\
\hline \multicolumn{8}{|c|}{ Pengetahuan praktik kesehatan di rumah } \\
\hline Kurang dan Sedang & 9 & 90 & 16 & 40 & 13,5 & \multirow{2}{*}{0,013} & \multirow[b]{2}{*}{$32 \%$} \\
\hline Baik & 1 & 10 & 24 & 60 & $(1,556-117,137)$ & & \\
\hline Total & 10 & 100 & 40 & 100 & & & \\
\hline \multicolumn{8}{|c|}{ Sikap praktik kesehatan di rumah } \\
\hline Kurang dan Sedang & 4 & 40 & 11 & 27,5 & 1,758 & \multirow{2}{*}{0,462} & \multirow{2}{*}{$9,6 \%$} \\
\hline Baik & 6 & 60 & 29 & 72,5 & $(0,415-7,441)$ & & \\
\hline Total & 10 & 100 & 40 & 100 & & & \\
\hline \multicolumn{8}{|l|}{ Paparan Asap Rokok } \\
\hline \multicolumn{8}{|c|}{ Keberadaan anggota keluarga yang merokok } \\
\hline Ada & 8 & 80 & 15 & 37,5 & 6,667 & \multirow{2}{*}{0,030} & \multirow{2}{*}{$27,3 \%$} \\
\hline Tidak ada & 2 & 20 & 25 & 62,5 & $(1,247-36,954)$ & & \\
\hline Total & 10 & 100 & 40 & 100 & & & \\
\hline \multicolumn{8}{|c|}{ Jumlah anggota keluarga yang merokok } \\
\hline$>2$ orang & 1 & 12,5 & 1 & 6,7 & 2 & \multirow{2}{*}{1,000} & \multirow{2}{*}{$20 \%$} \\
\hline$\leq 2$ orang & 7 & 87,5 & 14 & 93,3 & $(0,108-36,954)$ & & \\
\hline Total & 8 & 100 & 15 & 100 & & & \\
\hline \multicolumn{8}{|c|}{ Tempat merokok anggota keluarga yang merokok } \\
\hline \multirow{3}{*}{$\begin{array}{l}\text { Di luar dan di dalam } \\
\text { rumah } \\
\text { Di luar rumah }\end{array}$} & 6 & 75 & 4 & 26,7 & \multirow{3}{*}{$\begin{array}{c}8,25 \\
(1,154-59,003)\end{array}$} & \multirow{3}{*}{0,039} & \multirow{3}{*}{$44,6 \%$} \\
\hline & & 5 & 4 & 723 & & & \\
\hline & 2 & $\frac{25}{100}$ & $\frac{11}{15}$ & $\frac{73,3}{100}$ & & & \\
\hline Total & 8 & 100 & 15 & & & & \\
\hline
\end{tabular}

Pada balita di Puskesmas Putri Ayu menunjukkan hasil yang signifikan antara pengetahuan dan sikap ibu dengan perilaku ibu dalam melakukan pencegahan penyakit pneumonia pada anak. Anak dengan ibu berpengetahuan buruk akan memiliki risiko 3,34 kali lebih besar (Rahim, 2013). Penelitian Widyaningtyas (2016) juga mendukung penelitian ini dimana hasil penelitian menunjukkan sikap praktik kesehatan di rumah ibu yang baik ditunjukkan dalam perilaku ibu dalam tingkat sedang pada pengasuhan hygiene perorangan balita dan sanitasi lingkungan terhadap balita di Wilayah
Kerja Puskesmas Sumbersari Kabupeten Jember (Widyaningtyas, 2016).

\section{Paparan Asap Rokok}

Variabel paparan asap rokok yang memiliki hubungan dengan kejadian pneumonia anak 0-4 tahun adalah keberadaan anggota keluarga yang merupakan perokok dan tempat merokok, sedangkan besar jumlah anggota keluarga yang merokok tidak mempunyai hubungan yang signifikan. Penelitian sebelumnya pada 436 balita di Enugu Southeast Nigeria menunjukkan balita yang termasuk perokok pasif mempunyai risiko 
terkena acute respiratory tract infections sebesar 1,39 kali daripada balita yang bukan perokok aktif maupun pasif(Ujunwa and Ezeonu, 2014).

Perokok pasif (Second Hand Smoke) adalah orang bukan perokok yang menghirup asap rokok, dan akan ikut terkena dampak merokok yaitu terkena bahan kimia nikotin yang sama seperti dialami perokok (Stoppler, 2010). Indonesia memiliki angka prevalensi second-hand smoker yang tinggi dikarenakan tingginya jumlah perokok (first-hand smoker) dan banyaknya aturan tentang KTR yang tidak dipatuhi dengan baik.

Data

Riskesdas

2013 menunjukkan bahwa pada tahun 2013 terjadi peningkatan prevalensi perokok di Indonesia dari tahun 2007 sebesar $65,5 \%$ perokok laki-laki dan $5,2 \%$ perokok perempuan menjadi 68,8\% perokok lakilaki dan 6,9\% perokok perempuan. Sebanyak 97 juta orang non perokok di Indonesia secara regular terpapar asap rokok orang lain. Di Indonesia, 78,4\% perokok pasif terpapar asap rokok di dalam rumah (National Institute of Health Research and Development, 2011). Kondisi inilah yang memungkinkan anak sering terkena infeksi saluran pernafasan karena terkena paparan asap rokok dari anggota keluarganya, meskipun terdapat kemungkinan anggota keluarga tidak merokok didekat anak tetapi anak tetap bisa terpapar toksin yang ada di dalam rokok dikarenakan toksin yang terkandung dalam rokok dapat melekat pada pakaian dan rambut perokok. Apabila anggota keluarga merokok di luar rumah tetapi sampai di rumah langsung memegang anak tanpa membersihkan diri terlebih dahulu maka toksik yang menempel di baju dan rambut akan terhirup anak, inilah yang dinamakan dengan third hand smoker atau perokok pasif ketiga (Stoppler, 2010).

Penelitian yang dilakukan pada 46 anak umur 1-2 tahun di Kota Semarang menunjukkan adanya hubungan antara ayah yang memiliki status perokok dengan kejadian infeksi anak dimana anak yang mempunyai ayah seorang perokok akan berisiko terkena infeksi 3,34 kali lebih besar dibandingkan dengan anak yang memiliki ayah bukan perokok (Candra, 2014). Kejadian infeksi yang dimaksud dalam penelitian ini adalah infeksi pada saluran pernafasan dan/atau saluran pencernaan anak. Faktor yang mempengaruhi timbulnya infeksi ini adalah kondisi lingkungan yang buruk seperti terdapat banyak asap rokok di sekitar anak. Anak yang terpapar asap rokok baik secara langsung maupun tidak langsung dapat lebih mudah terkena pneumonia daripada orang dewasa dikarenakan ketika anak terpapar asap rokok anak dengan mudah akan terinfeksi mikroorganisme yang bisa merangsang pembentukan lendir, debu, dan bakteri dimana anak terutama balita tidak bisa mengeluarkan lendir atau debu dengan sendirinya. Kondisi ini yang membuat lendir dan debu tersebut terperangkap di dalam saluran pernafasan dan mengakibatkan udara tertahan di paru- paru sehingga dapat memecahkan kantong udara.

Penelitian lainnya menunjukkan hubungan yang bermakna antara variabel merokok dengan kejadian pneumonia balita di Puskesmas Siberida Kecamatan Batang Gansal dengan hasil terdapat $47,1 \%$ balita yang terkena pneumonia dan memiliki keluarga yang merokok, sedangkan balita yang tidak mengalami pneumonia dan mempunyai keluarga tidak merokok sebesar 28,6\% (Munthe and Wasiman, 2016). Penelitian lain yang dilakukan dengan melibatkan balita di Bantul, menunjukkan bahwa balita yang mempunyai anggota keluarga dengan kebiasaan merokok cenderung berisiko terkena pneumonia sebesar 2,35 kali dibandingkan balita yang tidak mempunyai anggota keluarga dengan kebiasaan merokok (Alnur, Ismail and Padmawati, 2017). Penelitian ini menunjukkan kepadatan hunian juga dapat mempengaruhi balita terkena pneumonia dengan besar risiko 2,2 kali apabila kepadatan hunian padat (Alnur, Ismail and Padmawati, 2017). Semakin banyak anggota keluarga balita apalagi anggota keluarga yang juga memiliki kebiasaan merokok dapat meningkatkan risiko balita terkena pneumonia. Penelitian sebelumnya menunjukkan hasil yang signifikan antara kebiasaan merokok dengan kejadian pneumonia balita di Puskesmas Pabuaran Tumpeng Kota Tangerang dengan tingkat risiko sebesar 1,269 pada balita yang mempunyai anggota dengan kebiasaan merokok (Wijaya and Bahar, 2014). Hasil dari penelitian ini tidak sama dengan 
hasil penelitian yang dilakukan oleh Hayati (2017), dimana hasil penelitian Hayati menunjukkan hasil variabel keberadaan anggota keluarga yang merupakan perokok tidak memiliki hubungan bermakna dengan kejadian pneumonia $(P$ Value 0,121$)$ dengan nilai OR 0,379 yang berarti balita yang memiliki anggota keluarga merokok memiliki faktor protektif sebesar 0,379 kali daripada balita yang tidak memiliki anggota keluarga merokok (Hayati, Suhartono and Winarni, 2017). Faktor yang mendominasi kebiasaan merokok anggota keluarga dipengaruhi oleh adanya keterpaparan informasi, baik informasi yang didapatkan secara langsung maupun tidak langsung (Dumilah, 2016).

Banyaknya jumlah perokok dalam penelitian ini tidak mempengaruhi kejadian pneumonia anak 0-4 tahun. Jumlah anggota keluarga dapat mempengaruhi kepadatan hunian rumah. Penelitian Prasetyo (2012) menjelaskan bahwa tidak ada hubungan antara kejadian pneumonia balita yang berada pada kelompok usia 6 bulan-5 tahun di Puskesmas Pengadegan Kecamatan Pengadegan Kabupaten Puralingga dengan kepadatan hunian rumah $(P$ Value 0,676) (Prasetyo, 2012).

Penelitian tentang tempat merokok didukung oleh penelitian Nugraha dan Rodiyatam (2016) pada 2931 balita di Wilayah Kerja UPTD Puskesmas Talaga Kabupaten Majalengka menunjukkan adanya hubungan bermakna antara tempat merokok dengan kejadian pneumonia pada balita $(P$ Value 0,002 ) (Nugraha and Rodiyatam, 2016). Penelitian lain yang dilakukan pada 138 balita di salah satu rumah sakit di Jakarta menunjukkan bahwa balita berisiko terkena pneumonia sebesar 2,53 kali apabila terdapat anggota keluarga dengan kebiasaan merokok di dalam rumah dibandingkan anggota keluarga dengan kebiasaan merokok tidak di dalam rumah (Hartati, Nurhaeni and Gayatri, 2012).

\section{SIMPULAN}

Perbedaan risiko $(R D)$ terbesar untuk kejadian pneumonia anak 0-4 tahun adalah variabel tempat merokok anggota keluarga yang merokok, kemudian diikuti variabel pengetahuan praktik kesehatan di rumah, keberadaan anggota keluarga yang merokok, jumlah anggota keluarga yang merokok, dan yang memiliki risiko terkecil adalah sikap ibu dalam praktik kesehatan di rumah. Pengetahuan dan dukungan keluarga berperan dalam mengurangi paparan asap rokok.

\section{DAFTAR PUSTAKA}

Alnur, R. D., Ismail, D. and Padmawati, R. S. (2017) 'Kebiasaan merokok keluarga serumah dan pneumonia pada balita', Berita Kedokteran Masyarakat, 33(3), pp. 119-124. doi: $10.22146 / \mathrm{bkm} .12832$.

Anggraini, R. (2015) Hubungan Asupan Energi, Protein dan Perilaku Hidup Bersih dan Sehat (PHBS) dengan Kejadian Pneumonia Pada Balita di Puskesmas Tawangsari Kabupaten Sukoharjo. Universitas Muhammadiyah Surakarta. Available at: http://eprints.ums.ac.id/36626/.

Badan Penelitian dan Pengembangan Kesehatan (2013) Riset Kesehatan Dasar 2013. Jakarta: Kementerian Kesehatan Republik Indonesia.

Candra, A. (2014) 'Faktor Risiko Infeksi Pada Anak 1-2 Th', Journal of Nutrition and Health, 2(1), pp. 112. 10.14710/jnh.2.1.2014.\%p.

doi:

Djaja, S., Wiryawan, Y. and Maisya, I. B. (2007) 'Tren Penyakit Penyebab Kematian Bayi dan Anak Balita di Indonesia dalam Periode Tahun 1992-2007', Jurnal Ekologi Kesehatan, 8(4), pp. 1100-1107. Available at: http://ejournal.litbang.depkes.go .id/index.php/jek/article/view/1 687.

Dumilah, R. (2016) 'Determinan Kebiasaan Merokok Kepala Keluarga pada Balita Penderita ISPA di Desa Karangharja', Jurnal Penelitian Kesehatan. AKADEMI KESEHATAN RAJEKWESI BOJONEGORO, 7(1). Available at: http://ejournal.rajekwesi.ac.id/i ndex.php/jurnal-penelitiankesehatan/article/view/107.

Handayani, R. (2017) 'Faktor-Faktor Yang Berhubungan Dengan Status Gizi Pada Anak Balita', Jurnal Endurance, 2(2), pp. 217-224. doi: 
10.22216/jen.v2i2.1742.

Handayani, R. W. (2016) Beberapa Faktor Risiko Kejadian Pneumonia pada Balita (Studi di Kecamatan Kalikajar Kabupaten Wonosobo. Universitas Diponegoro. Available at:

http: / /eprints.undip.ac.id/55989 l.

Hartati, S., Nurhaeni, N. and Gayatri, D. (2012) 'Faktor Risiko Terjadinya Pneumonia pada Anak Balita', Jurnal Keperawatan Indonesia, 15(1), pp. 13-20. doi: 10.7454/jki.v15i1.42.

Hayati, A. ., Suhartono and Winarni, S. (2017) 'Hubungan Antara Faktor Lingkungan Fisik Rumah Dengan Kejadian Pneumonia Pada Anak Balita Di Wilayah Kerja Puskesmas Semin I Kabupaten Gunung Kidul', Jurnal Kesehatan Masyarakat, 5(5), pp. 441-450.

Kemenkes RI (2017) 'Program Indonesia Sehat dengan Pendekatan Keluarga', Kementerian Kesehatan Republik Indonesia. Available at: https://www.depkes.go.id/article /view/17070700004/programindonesia-sehat-denganpendekatan-keluarga.html.

Kementerian Kesehatan RI (2011) Pedoman Pengendalian Infeksi Saluran Pernapasan Akut. Jakarta: Kementerian Kesehatan Republik Indonesia.

Klein, C. (2015) Teori Blum tentang Kesehatan Masyarakat. Available at:

https: / /dokumen.tips/documents /teori-blum-tentang-kesehatanmasyarakat.html .

Misnadiarly (2008) Infeksi Saluran Napas Pneumonia pada Anak, Orang Dewasa, Usia Lanjut, Pneumonia Atipik \& Pneumonia Atypik Mycobacterium. Jakarta: Pustaka Obor Populer.

Munthe, S. A. and Wasiman (2016) 'Jurnal Mutiara Kesehatan Masyarakat Jurnal Mutiara Kesehatan Masyarakat', Jurnal Mutiara kesehatan Masyarakat, 1(1), pp. 9-18. Available at: http://ejournal.sari-

mutiara.ac.id/index.php/JMKM/ar ticle/view/44.

National Institute of Health Research and
Development (2011) Global Adult Tobacco Survey : Indonesia Report 2011. New Delhi: World Health Organization.

Nugraha, Y. and Rodiyatam, I. (2016) 'Hubungan Kebiasaan Merokok Anggota Keluarga di Dalam Rumah Terhadap Kejadian Pneumonia Pada Balita Di Wilayah Kerja UPTD Puskesmas Talaga Kabupaten Majalengka Tahun 2016', Jurnal Kampus STIKES YPIB Majalengka, IV(10). Available at: http:/ / ejournal.stikesypib.ac.id/j urnal.php?detail=jurnal\&file=Yoph i Nugraha - HUBUNGAN KEBIASAAN MEROKOK ANGGOTA KELUARGA DI DALAM RUMAH TERHADAP KEJADIAN PNEUMONIA PADA BALITA DI WILAYAH KERJA UPTD PUSKESMAS TALAGA KABUPATEN MAJALENGKA TAHUN 2016.pdf\&id.

Nuretza, J. A., Suhartono and Winarni, S. (2017) 'Hubungan Antara Perilaku Keluarga Dan Kondisi Lingkungan Dalam Rumah Dengan Kejadian Pneumonia Pada Anak Balita Di Wilayah Kerja Puskesmas Halmahera Kota Semarang', Jurnal Kesehatan Masyarakat, 5(5), pp. 696-705. Available at: https://ejournal3.undip.ac.id/ind ex.php/jkm/article/view/19192.

Prasetyo, A. R. (2012) Analisis Faktor Risiko Kejadian Pneumonia pada Balita Usia 6 Bulan - 5 Tahun di Puskesmas Pengadegan Kecamatan Pengadegan Kabupaten Universitas Purbalingga. http://repository.ump.ac.id/6105 l.

Rahim, R. (2013) 'Hubungan Pengetahuan Dan Sikap Ibu Balita Dengan Pencegahan Penyakit Pneumonia Di Wilayah Kerja Puskesmas Putri Ayu Tahun 2013', Jambi Medical Journal, 1(1). Available at: https: / /www.neliti.com/publicati ons/70550/hubungan-

pengetahuan-dan-sikap-ibu-balitadengan-pencegahan-penyakitpneumonia-d.

Ryadi, A. L. S. (2016) Ilmu Kesehatan Masyarakat. Yogyakarta: Andi. Available

at: https: / /books.google.co.id/books /about/Ilmu_Kesehatan_Masyarak 
172 Jurnal Promkes: The Indonesian Journal of Health promotion and Health Education Vol. 7 No. 2 Desember 2019 : 163 - 172, doi: 10.20473/jpk.V7.12.2019.163-172

at.html?id=LPNrDQAAQBAJ\&redir esc $=y$.

Setiyarti, W. (2011) Hubungan Dukungan Suami dengan Pola Asuh Gizi pada Bayi Usia 6-12 Bulan di Desa Sukorejo Kecamatan Tegowanu, Grobogan. Universitas Muhammadiyah Semarang.

Stoppler, M. (2010) Perokok Pasif : Bahaya dan Efek- Efeknya. Available at: http://0.0.0.222/medicinenet.co $\mathrm{m} /$ secondhand_smoke_pictures_sl ideshow/article.htm (Accessed: 7 July 2018).

Tazinya, A. A. et al. (2018) 'Risk factors for acute respiratory infections in children under five years attending the Bamenda Regional Hospital in Cameroon', BMC Pulmonary Medicine. BMC Pulmonary Medicine, 18(7), pp. 18. doi: 10.1186/s12890-018-05797.

Ujunwa, F. and Ezeonu, C. (2014) 'Risk Factors for Acute Respiratory Tract Infections in Under-five Children in Enugu Southeast Nigeria', Annals of medical and health sciences research.
Medknow Publications \& Media Pvt Ltd, 4(1), pp. 95-99. doi: 10.4103/2141-9248.126610.

UNICEF (2018) Access The Data: UnderFive and Infant Mortality Rates and Number of Deaths, UNICEF. Available at: http://data.unicef.org/topic/chil d-survival/under-five-mortality/ (Accessed: 23 July 2018).

Widyaningtyas, D. (2016) Hubungan Pola Asuh Ibu dan Riwayat Imunisasi Dasar dengan Kejadian Pneumonia pada Balita di Puskesmas Sumbersari Kabupaten Jember. Universitas Jember. Available at: http://repository.unej.ac.id/hand le/123456789/78565.

Wijaya, I. and Bahar, H. (2014) 'Hubungan Kebiasaan Merokok, Imunisasi dengan Kejadian Pneumonia pada Balita di Puskesmas Pabuaran Tumpeng Kota Tangerang', Jurnal Forum Ilmiah, 11(3), pp. 375-385. Available at: https://ejurnal.esaunggul.ac.id/i ndex.php/Formil/article/view/10 86. 